\title{
Geologie en Mijnbouw / Netherlands Journal of Geosciences
}

\section{Scope}

Geologie en Mijnbouw / Netherlands Journal of Geosciences seeks to be the prime outlet for publication of geoscientific papers pertaining to the Netherlands and the North Sea region and relevant adjacent areas. Manuscripts on any geoscientific topic will be considered for publication, provided they comply with the regional focus of the journal and are of international interest and quality.

\section{Submission of manuscripts}

Manuscripts may be submitted to the Editorial Office. Manuscripts should be prepared in accordance with the 'instructions to authors' as summarized in every first issue of a volume; the instruction is also available upon request from the Editorial Office and on the journal's website (http://www.nitg.tno.nl/eng/products/pub/njg/ index.shtml). The author(s) of manuscripts submitted are responsible for obtaining clearance for publication from relevant parties including, if appropriate, permission to include copyright material.

\section{Subscription and distribution}

Geologie en Mijnbouw / Netherlands Journal of Geosciences is published quarterly and dispatched by surface post. The journal is distributed to members of the Royal Geological and Mining Society of the Netherlands (KNGMG) free of charge and to private and institutional subscribers. The rate for institutional subscribers for the year 2001 is NLG 560.00 / US\$233.00 / Euro 254.00. Subscriptions are handled by Veenman drukkers, P.O. Box 18, 6710 BA Ede, the Netherlands (tel. +31-318-648400; fax +31-318-648484; e-mail: users@veenman-druk.nl).

All orders (including requests for back issues) and related business correspondence (including address changes for subscribers) should be addressed to Veenman drukkers.

\section{Advertisements}

For advertisements in Geologie en Mijnbouw / Netherlands Journal of Geosciences, please contact Tonny Handgraaf, Retra Publiciteitsservice b.v., P.O. Box 333, 2040 AH Zandvoort, the Netherlands (tel. +31-23-5718480; fax +31-23-5716002; e-mail tonny@retra.nl).

The forthcoming issue will be published in September 2001. The closing date for advertisements is August 15, 2001.

\section{Abstracting and indexing}

Geologie en Mijnbouw / Netherlands Journal of Geosciences is indexed/abstracted in Biological Abstracts, Current Contents/Physical, Current Geographical Publications, Chemical \& Earth Sciences, Geological Abstracts, GeoArchive \& GeoTitles, Science Citation Index Expanded, ASCA, Cambridge Scientific Abstracts, INSPEC Information Services Petroleum Abstracts, Bibliography and Index of Geology, GeoRef, Geobase/GeoAbstracts, Chemical Abstracts, The ISI Alerting Services.

\section{Copyright and photocopying}

(C) Stichting Netherlands fournal of Geosciences.

The journal (ISSN 0016-7746) is registered with the Copyright Clearance Center (CCC), 222 Rosewood Drive, Danvers, MA 01923, USA. Authorization to photocopy items for internal or personal use is granted by the Stichting Netherlands fournal of Geosciences, provided that the appropriate fee is paid directly to CCC. Prior to photocopying, please get permission online at the CCC website (http://www.copyright.com) or call the CCC (+1-978-750-8400), which can also be contacted for information about additional usage of material.

Requests for permission to reproduce material published in this journal for other publications should be addressed to the Editorial Office. 
Contents volume 80, No. 2 (June 2001)

Environmental conditions and palaeowind directions at the end of the Weichselian

Late Pleniglacial recorded in aeolian sediments and geomorphology (Twente,

Eastern Netherlands)

J. van Huissteden, J.C.G. Schwan \& M.D. Bateman

The climate in The Netherlands during the Younger Dryas and Preboreal: means and extremes obtained with an atmospheric general circulation model

H. Renssen

Vertebrate track bed stratigraphy of the Röt and basal Lower Muschelkalk (Anisian) of Winterswijk (East Netherlands)

C. Diedrich

FT-IR and RAMAN microscopic study at $293 \mathrm{~K}$ and $77 \mathrm{~K}$ of celestine, SrSO4, from the Middle Triassic limestone (Muschelkalk) in Winterswijk, The Netherlands

J. Theo Kloprogge, Huada Ruan, Loc V. Duong and Ray L. Frost

Laser-diffraction and pipette-method grain sizing of Dutch sediments: correlations

for fine fractions of marine, fluvial, and loess samples

P. Buurman, Th. Pape, J. A. Reijneveld, F. de Jong and E. van Gelder

The atlas of structural geometry: a digital collection of 25 years of analogue modelling

D.A. Nieuwland and M. Nijman

Forthcoming papers

Guide for authors

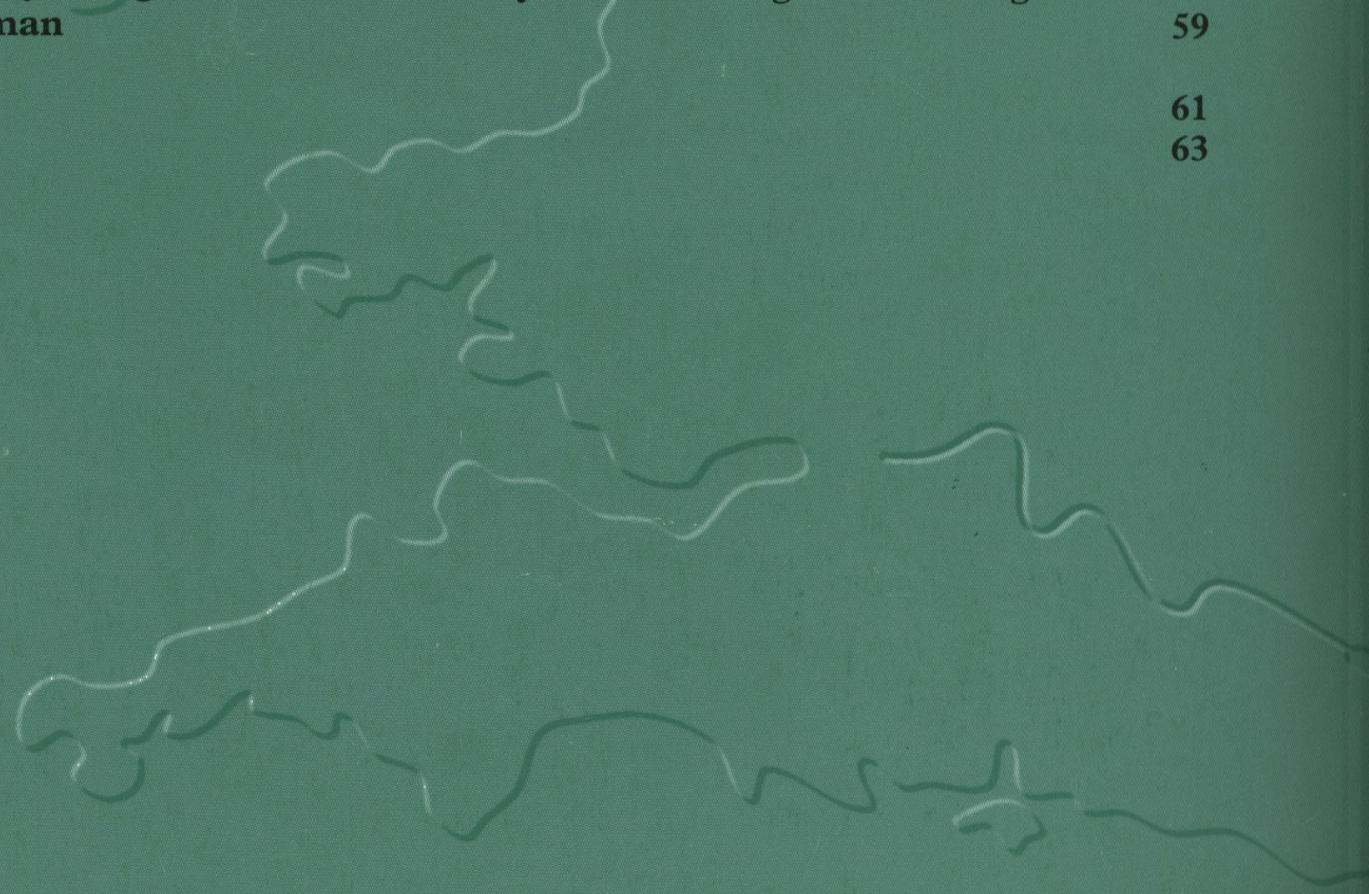

